Rafat Michatowski ${ }^{1}$

\title{
Zasady przetargowego trybu sprzedaży nieruchomości Zasobu Własności Rolnej Skarbu Państwa
}

\section{Uwagi wstępne i ustalenia terminologiczne}

Problematyka przetargowego trybu sprzedaży nieruchomości z Zasobu Własności Rolnej Skarbu Państwa ${ }^{2}$ należy do najważniejszych materii regulowanych przez ustawę z dnia 19 października 1991 r. o gospodarowaniu nieruchomościami rolnymi Skarbu Państwa ${ }^{3}$, mając na uwadze sformułowany w art. 6 katalog celów, których realizację ustawodawca powierzył Agencji Nieruchomości Rolnych. Problematyka zasad postępowania przetargowego przy sprzedaży nieruchomości ZWRSP dotychczas nie cieszyła się szczególnym zainteresowaniem w piśmiennictwie, co uzasadnia podjęcie tego tematu.

W rozważaniach autorów zajmujących się problematyką zasad zbywania nieruchomości publicznych brakuje wyczerpującego wyjaśnienia, co rozumieją pod pojęciem zasady w kontekście, w jakim zostaje użyty ów termin. Uzasadnia to, przed przystąpieniem do analizy wyróżnionych przez nich zasad, wyjaśnienie najpowszechniej przyjętego $\mathrm{w}$ teorii prawa sposobu ich pojmowania.

Przede wszystkim dzieli się zasady prawa na zasady w ujęciu dyrektywalnym oraz opisowym. Zasadą w sensie dyrektywalnym jest norma prawna w jakimś sensie nadrzędna względem innych norm, niebędących zasadami. Przy tym nie musi tu chodzić o hierarchiczną relację nadrzędności między tymi normami, ale również o to, że pomimo iż norma - zasada pozostaje na tym samym poziomie z normami, względem których ustala się jej „,zasadniczość”, jeśli chodzi o ich relacje hierarchiczne, to norma - zasada pełni szczególną rolę w ukształtowaniu danej instytucji

Dz.U. z 2007 r. Nr 231, poz. 1700 z późn. zm. przywoływana dalej jako u.g.n.r. Szczególnie istotne dla omawianej problematyki jest również wydane na podstawie art. 32 u.g.n.r. rozporządzenie Ministra Rolnictwa i Rozwoju Wsi z dnia 17 lutego 2010 r. w sprawie szczegółowego trybu sprzedaży nieruchomości Zasobu Własności Rolnej Skarbu Państwa i ich części składowych, warunków rozkładania ceny sprzedaży na raty oraz stawek szacunkowych gruntów (Dz.U. Nr 29, poz. 151), przywoływane dalej jako rozporządzenie z dnia 17 lutego $2010 \mathrm{r}$. 
prawnej ${ }^{4}$. W sensie opisowym zaś zasada prawa to wzorzec ukształtowania jakiejś instytucji prawnej - wzorzec pomyślany (tak a tak można by ukształtować jakąś instytucję) bądź odtworzony na podstawie obowiązujących norm ${ }^{5}$. W tym ostatnim przypadku tak ujmowana zasada jest wynikiem analizy sposobu ukształtowania instytucji prawnej bądź ich zespołu ,przełożona” na wypowiedzi o charakterze opisowym, ujmujące sprawozdawczo, jak ukształtowana jest ta instytucja (bądź ich zespół).

Warto zaznaczyć, że w literaturze stosunkowo niedawno wyrażono pogląd, że zasady prawa (w sensie dyrektywalnym) stanowią nośnik wartości (aprobowanych stanów rzeczy), wprowadzonych do systemu prawa przez prawodawcę. Przy tym podkreśla się, że nie są one jeszcze jednym rodzajem norm, ale stanowią „swoistą postać zbioru elementów należących do innej kategorii ontologicznej, do kategorii

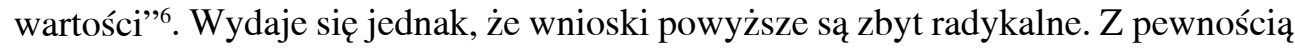
normy - zasady wskazują, czy - ściśle rzecz ujmując - nakazują realizację jakichś wartości, ale twierdzenie, że takie normy nie wyznaczają w wystarczająco precyzyjny sposób obowiązków nakładanych na adresatów, nie jest przekonujące. Dużo zależy wszak od tego, kto jest adresatem, w jakich okolicznościach ma obowiązek zachować się zgodnie z dyspozycją takiej normy, a także kto i jak ustala, czy takie normy są realizowane. Warto również wskazać, że fundamentalna dla prawa cywilnego zasada swobody umów w wersji dyrektywalnej jest normą prawną, a podstawowy dla jej rekonstrukcji art. $353^{1} \mathrm{kc}$. ma charakter przepisu zrębowego ${ }^{7}$ - nie jest więc tak, że w szacie językowej właściwej dla norm prawnych zasady prawa są zawsze jedynie nośnikami wartości, jakkolwiek rzeczywiście tak jest najczęściej.

Mimo że o zasadach szczególnie często wspomina się czy też rekonstruuje je w rozważaniach o dużym stopniu ogólności (np. zasady prawa cywilnego) na tle aktów prawnych o szczególnie istotnym dla danej dziedziny stosunków społecznych charakterze (w szczególności kodeksów), to w moim odczuciu nic nie stoi na przeszkodzie, aby czynić to w toku rozważań o większym stopniu szczegółowości, na gruncie regulacji nawet dość wąsko określonych dziedzin stosunków społecznych, jak na przykład sprzedaż nieruchomości publicznych dokonywana przez Agencję Nieruchomości Rolnych (dalej: ANR). Uzasadnione jest to, zwłaszcza jeśli uprzednio uzna się, że pomimo wąskiego zakresu oddziaływania dana regulacja ma dużą doniosłość społeczną. Zabieg taki jest ze wszech miar pożyteczny i przyczynia się do uporządkowania problematyki przetargowej sprzedaży nieruchomości Zasobu

\footnotetext{
4 S. Wronkowska, System prawny a porządek prawny i ład społeczny, (w:) S. Wronkowska, Z. Ziembiński, Zarys teorii prawa, Poznań 2001, s. 187.

Ibidem

M. Kordela, Zasady prawa jako normatywna postać wartości, RPEiS 2006, nr 1, s. 41.

Por. P. Machnikowski, Swoboda umów według art. 3531 kc. Konstrukcja prawna, Warszawa 2005, s. 138.
} 
Zasady przetargowego trybu sprzedaży nieruchomości Zasobu Własności Rolnej...

Własności Rolnej Skarbu Państwa w szczególności jako źródło szczegółowych dyrektyw interpretacyjnych $w$ interesującym nas zakresie ${ }^{8}$.

\section{Zasady postępowania przetargowego przy sprzedaży nieruchomości ZWRSP}

\subsection{Zasady gospodarowania mieniem publicznym w poglądach doktryny}

W doktrynie podejmowano już próby sformułowania, z reguły na gruncie ustawy z dnia 21 sierpnia 1997 r. o gospodarce nieruchomościami ${ }^{9}$, nie tylko zasad postępowania przetargowego, ale szerzej - zasad zbywania nieruchomości publicznych. Potwierdzenie zasadności ich sformułowania i uzasadnienie dostatecznego stopnia uniwersalności, czy też może - innymi słowy - „dopasowania” do mechanizmów sprzedaży przetargowej nieruchomości Zasobu wyznaczonych przepisami u.g.n.r. pozwoli na ich wkomponowanie do analizy materii regulowanej przez tę ustawę. Z góry należy zastrzec, że spora część sformułowanych w doktrynie zasad dotyczy gospodarowania mieniem publicznym w ogólności, niekoniecznie tylko przetargowego trybu rozporządzania nim. Stąd konieczne będzie każdorazowe określenie, w jakich aspektach dana zasada mająca szerszy zakres oddziaływania znajduje odzwierciedlenie w szczegółowych regulacjach przetargowego trybu sprzedaży nieruchomości Zasobu.

R. Pessel, prowadzący swoje rozważania na tle regulacji zarówno u.g.n., jak i innych aktów prawnych, których przedmiotem jest gospodarka nieruchomościami Skarbu Państwa (w tym u.g.n.r.), wymienia trzy zasady gospodarowania mieniem: prawidłowej gospodarki nieruchomościami, jawności gospodarowania nieruchomościami Skarbu Państwa oraz realizacji celów publicznych ${ }^{10}$. W odniesieniu do problematyki sprzedaży nieruchomości na tle przepisów u.g.n. wymienia zasady: zbywania nieruchomości w trybie przetargowym, a na podstawie art. 42 ust. 1 u.g.n. również jawności i jednolitości postępowania, równego dostępu do udziału w przetargu oraz najkorzystniejszego wyniku przetargu. ${ }^{11}$

Zwłaszcza na interpretacyjną rolę zasad prawa zwraca uwagę M. Safjan, (w:) System prawa prywatnego, t. 1, Prawo cywilne - część ogólna, pod red. M. Safjana, Warszawa 2007, s. 263. Ów autor jednocześnie przestrzega przed formułowaniem zbyt dużej ilości zasad ze względu na to, że prowadzi to do niepotrzebnych sporów o to, które zasady rzeczywiście obowiazują. Formułowanie natomiast zbyt szczegółowych zasad powoduje, że nie posiadają one wystarczającego waloru ogólności, co jest szczególnie istotne ze względu na ich funkcję wystarczająco ogólnej dyrektywy wykładni; ibidem, s. 269. Doceniając doniosłość zgłoszonych przez Autora zastrzeżeń, chcę zaznaczyć, że przy dostatecznie precyzyjnym zakreśleniu zakresu zasad prawa formułowanych na gruncie nawet dość szczegółowych regulacji, podając w miarę precyzyjne kryteria ich wyodrębnienia, można uniknąć wskazywanych przez niego negatywnych skutków. Natomiast sam konflikt zasad jest w sumie zjawiskiem nieuniknionym, ale w literaturze można odnaleźć udane próby sformułowania kryteriów pozwalających na ich rozstrzyganie; zob. w szczególności: T. Gizbert-Studnicki, Konflikt dóbr i kolizja norm, RPEiS 1989, nr 1, s. 1 i nast.

$9 \quad$ Dz.U. z 2010 r. Nr 102, poz. 651 z późn. zm., przywoływana dalej jako u.g.n.

10 R. Pessel, Nieruchomości Skarbu Państwa, Warszawa 2008, s. 73 i nast.

11 Ibidem, s. 195 i nast. 
R. Padrak wyróżnił w tym zakresie następujące zasady: przetargu, respektowania przepisów o pomocy publicznej, pierwszeństwa, jawności i jednolitości postępowania, równego dostępu do udziału w przetargu oraz najkorzystniejszego wyniku przetargu $^{12}$. Z kolei M. Stańko, odnosząc swoje uwagi do gospodarki nieruchomościami gminnymi, powiatowymi i wojewódzkimi, sformułował zasady: reprezentacji, racjonalnej (prawidłowej) gospodarki, ekwiwalentności, jawności oraz przetargowego zbywania nieruchomości ${ }^{13}$.

\subsection{Umiejscowienie zasad postępowania przetargowego} w obrębie regulacji sprzedaży nieruchomości ZWRSP

Najbardziej ogólnie sformułowane zasady gospodarowania mieniem publicznym dokonane przez R. Pessela na gruncie u.g.n.r. wymagają pewnych uściśleń. Autor stwierdza, że prawidłowe gospodarowanie nieruchomościami ZWRSP polegać ma na wykonywaniu wyliczonych w art. 6 zadań, które mają swoje odzwierciedlenie w rocznym planie finansowym Zasobu oraz ANR (art. 20 ust. 2 pkt 1 i 2). Takie sformułowanie zasady prawidłowej gospodarki odwołuje się raczej do sfery stosowania postanowień ustawy, a nie wykładni normy nakazującej gospodarować mieniem Zasobu w określony sposób. Poza tym, nie do końca jasne jest, jaki wpływ na wykonywanie zadań mają postanowienia planu finansowego Agencji (będącego przecież czymś innym niż plan finansowy Zasobu). Chyba mamy tu do czynienia jedynie $\mathrm{z}$ wpływem pośrednim, skoro środki uzyskane $\mathrm{z}$ gospodarowania mieniem Zasobu są wykorzystywane m.in. na funkcjonowanie ANR. Ostatecznie uważam, że dla wskazania podstawy dla sformułowania zasady prawidłowej gospodarki mieniem Zasobu należy ograniczyć się do postanowień art. 6. W szczególności zasada prawidłowej gospodarki w ujęciu dyrektywalnym ma swoje odzwierciedlenie w postanowieniach art. 6 ust. 1 pkt 2 u.g.n.r., mówiącego o tworzeniu warunków sprzyjających racjonalnemu wykorzystaniu potencjału produkcyjnego ZWRSP. Jeśliby jednak mówić o obowiązku prawidłowej realizacji zadań nałożonych na Agencję w kontekście przetargowej sprzedaży nieruchomości Zasobu, to uznać należy, że z samego katalogu zadań ANR nie wynikają takie nakazy ani zakazy, których naruszenie skutkować by mogło nieważnością umowy sprzedaży nieruchomości ZWRSP. Z pewnością należy brać je pod uwagę przy dokonywaniu wykładni przepisów dotyczących prawnych form gospodarowania mieniem Zasobu, a więc i sprzedaży w drodze przetargu. Nie są one jednak samodzielną podstawą dla dekodowania norm prawnych regulujących szczegółowe kwestie dotyczące trybu postępowania zmierzającego do sprzedaży gruntów ZWRSP. Biorąc je pod uwagę, Agencja, na etapie podjęcia decyzji o zamiarze zbycia konkretnego składnika Zaso-

R. Padrak, Sprzedaż nieruchomości samorządowych i Skarbu Państwa na podstawie ustawy o gospodarce nieruchomościami, Wrocław 2010, s. 13 i nast.

13 M. Stańko, Prawne formy gospodarowania składnikami mienia komunalnego w przepisach szczegółowych, (w:) J. Jagoda, D. Łobos-Kotowska, M. Stańko, Gospodarka mieniem komunalnym, Warszawa 2008, s. 92. 
bu, powinna jednak rozważyć, czy bardziej korzystna z punktu widzenia racjonalnej realizacji jej zadań będzie sprzedaż, czy też wybór innej formy zagospodarowania. W razie podjęcia decyzji o sprzedaży - zdecydować ze względu na cechy nieruchomości oraz lokalne uwarunkowania o wyborze procedury nieograniczonej, w założeniu zapewniającej korzystniejszy dla organizatora efekt ekonomiczny transakcji albo ograniczonej, przyczyniający się do wsparcia przemian strukturalnych gospodarstw rolnych w kierunku wyznaczonym przez ustrojodawcę w Konstytucji (art. 23). Jednak w razie zbycia gruntu w procedurze nieograniczonej, pomimo celowości w konkretnych okolicznościach przeprowadzenia przetargu ograniczonego ${ }^{14}$, w żadnym przypadku nie można mówić o sprzeczności dokonywanych czynności z przepisami u.g.n.r. rodzących jakiekolwiek sankcje, w szczególności nieważność zawartej w tym trybie umowy na podstawie art. $58 \S 1 \mathrm{kc} .^{15}$

Nie ma raczej podstaw, aby szczególnie eksponować w obrębie regulacji przetargowej sprzedaży gruntów Zasobu zasadę respektowania przepisów o pomocy publicznej, o której wspomina R. Padrak. W § 7 ust. 1 pkt 11 oraz $§ 24$ ust. 2 pkt 2 rozporządzenia $\mathrm{z}$ dnia 17 lutego 2010 r. prawodawca zawarł postanowienia dotyczące uzyskania pomocy publicznej w postaci rozłożenia ceny sprzedaży na raty z zastosowaniem oprocentowania preferencyjnego. Należy doceniać praktyczną rolę tych rozwiązań, jednak trudno doszukać się dostatecznie ważnych racji celowościowych uzasadniających wyodrębnienie ich w postaci zasady w ramach trybu przetargowego. Nie determinują one w żaden sposób charakterystycznych elementów konstrukcji tego trybu zawarcia umowy.

Wymieniona na tle u.g.n. przez M. Stańkę zasada reprezentacji wydaje się być osadzona w postanowieniach przepisów ustrojowych oraz w przepisach u.g.n. wskazujących organy reprezentujące Skarb Państwa oraz j.s.t. przy gospodarowaniu mieniem publicznym. Jej „przełożenie” do regulacji u.g.n.r. wymagałoby odniesienia do powierniczego statusu ANR. Status ANR jako instytucji powierniczej nieraz był już przedmiotem rozważań doktrynalnych ${ }^{16}$. Nie wydaje się, aby należało ją uwypuklać w obrębie regulacji przetargowego trybu zbycia nieruchomości Zasobu jako odrębną zasadę. Jest tak dlatego, że przepisy określające konstrukcję przetargu na sprzedaż nieruchomości ZWRSP nie noszą jakiegoś szczególnego piętna dyktowa-

14 Przykładowo, gdyby w razie stwierdzenia wyraźnego zainteresowania nabyciem gruntu przez rolników prowadzących gospodarstwa rodzinne w rozumieniu u.k.u.r., zwłaszcza w regionach charakteryzujących się rozdrobnioną struktura gospodarstw, ANR sprzedałaby grunt w procedurze nieograniczonej, a nabywca zostałaby osoba nielegitymująca się kwalifikacjami rolnymi i niezamierzająca powadzić działalności rolniczej.

Por. wydany na tle u.g.n. wyrok SN z dnia 6 marca 2009 r., II CSK 589/08, Lex nr 530697, w którego uzasadnieniu zawarto stwierdzenie, że naruszenie zasad prawidłowej gospodarki (gdy chodzi o przeznaczenie nieruchomości do zbycia bądź wybór formy przetargu) nie powoduje nieważności przetargu ani umowy zawartej w jego wyniku).

A. Doliwa, Ustawowe powiernictwo wykonywania własności państwowej na przykładzie Agencji Własności Rolnej Skarbu Państwa, „Studia Prawnicze” 2003, nr 1, s. 107 i nast.; P. Stec, Powiernictwo w prawie polskim na tle porównawczym, Kraków 2005, s. 222-223; R. Rykowski, Pojęcie powiernictwa - konstrukcja prawna zarządu powierniczego, Warszawa 2005, s. 116-125. 
nego powierniczym statusem ANR; aspekt podmiotowy pozostaje niejako „w tle” tej regulacji.

Będący podstawą dla sformułowania zasady ekwiwalentności art. 30 ust. 1 u.g.n.r. stanowi, że cena nieruchomości ustalana jest na poziomie nie niższym niż jej wartość ustalona przy zastosowaniu sposobów określonych w przepisach u.g.n. W drodze wyjątku od tego postanowienia ustawodawca dopuszcza możliwość ustalenia ceny nieruchomości rolnej nieprzeznaczonej w planie zagospodarowania przestrzennego na cele niezwiązane z prowadzeniem gospodarki rolnej lub leśnej, z uwzględnieniem stawek szacunkowych 1 hektara oraz ceny kwintala żyta ustalonej stosownie do przepisów o podatku rolnym ${ }^{17}$. Należy również zauważyć, że zgodnie z art. 29 ust. 3a u.g.n.r. w razie nierozstrzygnięcia kolejnego przetargu, przy ogłaszaniu kolejnych przetargów Agencja może ustalić niższą cenę wywoławczą, nie niższą jednak niż połowa ceny wywoławczej ustalonej według art. 30 (zob. też $\S 8$ ust. 4 i 5 rozporządzenia $\mathrm{z}$ dnia 17 lutego 2010 r.). Z zasady ekwiwalentności, rozpatrywanej w kontekście regulacji przetargu, wynika konieczność ustalania ceny wywoławczej na poziomie nie niższym niż wskazana w art. 30 u.g.n.r. Wydaje się być ona na tyle istotna, że zasługuje na jej odrębne zaakcentowanie. Wyznacza ona minimalny pułap ${ }^{18}$, od którego zaczyna się rywalizacja uczestników ubiegających się o zawarcie umowy. Oczywiście w sytuacjach określonych przepisami, a wskazanych powyżej, określona w wyniku przeprowadzonego przetargu cena nieruchomości może być od niej niższa.

Zasady ekwiwalentności w tym ujęciu oczywiście nie należy utożsamiać z ekwiwalentnością taką, jak ją się niekiedy definiuje przy analizie charakteru cywilnoprawnych umów wzajemnych. W tym ostatnim przypadku, zdaniem części doktryny, chodzi wszak tylko o subiektywną równowartościowość świadczeń ${ }^{19}$. W przypadku zaś zasady ekwiwalentności przy zbywaniu nieruchomości ZWRSP (czy też szerzej: nieruchomości publicznych) chodzi o ustalenie rozmiaru należnego świadczenia kupującego (jest to punkt wyjściowy, gdyż zostaje on określony w toku rywalizacji uczestników) na określonym poziomie na podstawie obiektywnych, ustawowych kryteriów.

Zasada pierwszeństwa, eksponowana przez R. Padraka, została sformułowana jako przeciwwaga dla zasady przetargowego trybu sprzedaży nieruchomości publicznych. Stąd ustalenie jej zakresu jednocześnie pozwala wyznaczyć zakres okoliczności, w których rozporządzanie nieruchomościami ZWRSP w drodze przetargu

Zob. art. 6 ust. 2 ustawy z dnia 15 listopada 1984 r. o podatku rolnym (Dz.U. z 2006 r. Nr 136, poz. 969 z późn. $\mathrm{zm}$.).

18 Cena wywoławcza może wszak być ustalona na poziomie wyższym, zależnym od uznania organizatora.

19 W. Czachórski, A. Brzozowski, M. Safjan, E. Skowrońska-Bocian, Zobowiązania. Zarys wykładu, Warszawa 2004, s. 132. Bardziej przekonujący jest jednak pogląd Z. Radwańskiego, twierdzącego, że umowy wzajemne charakteryzuje sprzężenie świadczeń, co odzwierciedla paremia do ut des; Z. Radwański, A. Olejniczak, Zobowiązania - część ogólna, Warszawa 2005, s. 119. 
jest obligatoryjne, na zasadzie, że gdzie wchodzi w grę pierwszeństwo, wyłączony jest przetarg. Pierwszeństwo uregulowane jest w art. 29 ust $1-1$ g u.g.n.r. oraz w $\S$ 5 rozporządzenia z dnia 17 lutego 2010 r. Mówienie o przeciwwadze pierwszeństwa dla przetargowego trybu sprzedaży nieruchomości ZWRSP jest uzasadnione, jeśliby przyjąć (a jest to myśl nieraz przywoływana w rozważaniach doktrynalnych ${ }^{20}$ ), że pierwszeństwa nie należy traktować jako wyjątku od zasady przetargu, ale równorzędny z nim sposób zbywania nieruchomości publicznych. W tej sytuacji, przy wykładni przepisów dotyczących pierwszeństwa nie znajdowałaby zastosowania reguła exceptiones non sunt extendendae. Nie sposób bagatelizować czy też pomijać instytucję pierwszeństwa przy prowadzeniu rozważań nad przetargowym trybem sprzedaży gruntów ZWRSP. Jednak należy mieć przy tym na uwadze, że nie ma ona istotnego znaczenia dla analiz mających za przedmiot samą konstrukcję i mechanizm tego trybu zawarcia umowy. Powtórzę, że jest niezwykle istotna właśnie dla ustalenia zakresu okoliczności, w których przetarg jest obligatoryjny.

Jawność w dysponowaniu mieniem publicznym jest zasadą powszechnie uwypuklaną zarówno w orzecznictwie, jak i w piśmiennictwie ${ }^{21}$. Istotne znaczenie dla jej wyznaczenia ma, na gruncie u.g.n.r., przepis art. $28^{22}$ stanowiący o obowiązku sporządzenia i podania do publicznej wiadomości wykazu nieruchomości przeznaczonych do zbycia. Kolejnymi przejawami zasady jawności jest regulacja dotycząca udostępnienia ogłoszenia przetargu. Jak stanowi § 7 ust. 1 rozporządzenia z dnia 17 lutego 2010 r., przetarg ogłaszany jest przez organizatora w sposób zwyczajowo przyjęty w miejscowości, w której położona jest nieruchomość. W procedurze przetargu ograniczonego jawności postępowania podporządkowany jest obowiązek komisji przetargowej wywieszenia $\mathrm{w}$ miejscu podanym $\mathrm{w}$ ogłoszeniu przetargu listy osób zakwalifikowanych do uczestnictwa w przetargu lub listy podmiotów, które nie złożyły w terminie wymaganych dokumentów (zob. § 16 ust. 2 pkt 3 i 4). Natomiast zgodnie z brzmieniem $\S 17$, w przypadku przetargu ofert komisja przetargowa może dopuścić jawność dokonywanych czynności (z wyjątkiem oceny złożonych

20 Doktryna odwołuje się do uchwały Trybunału Konstytucyjnego z dnia 18 czerwca 1996 r., W 19/95, OTK 1996, nr 3, poz. 25.

21 Oprócz prac powołanych wyżej zob. G. Bieniek, Sprzedaż nieruchomości skarbowych i samorządowych (w:) G. Bieniek, S. Rudnicki, Nieruchomości. Problematyka prawna, Warszawa 2009, s. 741-742. W orzecznictwie dla problematyki jawności postępowania podstawowe znacznie ma wyrok SN z dnia 11 maja 2005 r. III CK 562/04, Biul. SN 2005, nr 9, s. 11, Lex nr 155352. Zob. również wyr. NSA z dnia 21 marca 2007 r., I OSK 1998/06, Lex nr 327775, gdzie w uzasadnieniu zawarto stwierdzenie, że kardynalnym motywem wprowadzenia szczególnego reżimu zbywania nieruchomości publicznych jest konieczność zapewnienia „niezbędnej w takich przypadkach przejrzystości". Stąd jawność może być postrzegana jako jeden z najważniejszych instrumentów służących zapewnieniu przejrzystości (transparentności) postępowania zmierzającego do sprzedaży nieruchomości publicznych. M. Stańko stwierdza nawet, że „z zasady jawności można wyprowadzić wniosek o charakterze ogólnym - nawet gdy przepis wprost nie określa, czy dana czynność (procedura) ma zostać upubliczniona, to obowiązek taki wynika z zasady transparentności działania organów w sferze publicznej”; M. Stańko, Prawne formy gospodarowania składnikami mienia komunalnego w przepisach szczegółowych (w:) J. Jagoda, D. Łobas-Kotowska, M. Stańko, Gospodarka mieniem komunalnym, op. cit., s. 100.

Znaczenie wykazu nie ogranicza się tylko do przetargowego trybu sprzedaży nieruchomości Zasobu, gdyż sporządza się go i publikuje również przy sprzedaży bezprzetargowej. Dlatego uzasadnione jest stwierdzenie, że upublicznienie wykazu nie jest etapem procedury przetargowej, ale stadium go poprzedzającym. 
ofert). To ostatnie rozwiązanie, nie obligujące, a pozostawiające komisji swobodę co do powzięcia decyzji o jawności dokonywanych przez nią czynności, budzi sprzeciw. Przypomnieć trzeba, że przy sprzedaży nieruchomości zurbanizowanych czynności komisji, poza etapem postępowania polegającym na analizie i wyborze najkorzystniejszej oferty, są jawne, a komisja nie ma kompetencji do podjęcia innej decyzji w tym zakresie (por. $\S 18$ ust. 2, $\S 19$ ust. 1 i $\S 22$ ust. 1 rozporządzenia z dnia 14 września 2004 r.). W tym kierunku ukształtowane powinny być również odnośne przepisy u.g.n.r.

Autorzy wyróżniający na gruncie u.g.n. zasady jawności i jednolitości postępowania, równego dostępu do udziału w przetargu oraz najkorzystniejszego wyniku przetargu czynią to, biorąc za podstawę brzmienie art. 42 ust. 1 u.g.n. zawierającego upoważnienie do wydania rozporządzenia określającego sposób i tryb przeprowadzania przetargów na zbycie nieruchomości skarbowych i samorządowych. Jakkolwiek mogłoby się wydawać, że rekonstruowanie zasad instytucji prawnej z treści upoważnienia do wydania aktu podustawowego nie jest nadmiernie fortunnym zabiegiem, to jego staranna lektura uzasadnia konstatację, że ów przepis podaje najbardziej istotne, węzłowe aspekty konstrukcji przetargu na nieruchomości skarbowe i samorządowe. Wniosek ten znajduje uzasadnienie również w orzecznictwie $\mathrm{SN}^{23}$.

Nie do końca zrozumiałe jest, dlaczego prawodawca posłużył się koniunkcją ,jawność i jednolitość postępowania”, co sugeruje, że mamy do czynienia z jedną zasadą, ewentualnie dwiema w szczególny sposób połączonymi ze sobą zasadami. Jednak między zasadą jawności rozumianą jako nakaz publicznego dokonywania oznaczonych czynności lub publicznego udostępniania ich wyników oraz jednolitością rozumianą jako zakaz indywidualnego dokonywania modyfikacji bądź indywidualnego uzgadniania warunków postępowania przetargowego ${ }^{24}$ nie istnieje jakieś szczególne powiązanie treściowe bądź funkcjonalne, wykraczające poza związki łączące je z pozostałymi, wymienionymi tam zasadami. Stąd o jednolitości oraz jawności należałoby mówić jako odrębnych zasadach ${ }^{25}$.

Zob. wyrok SN z dnia 30 stycznia 2009 r. II CSK 437/08, Lex nr 599752, w którym formułuje się zasady przetargu przy bezpośrednim odwołaniu do treści art. 42 ust. 1 u.g.n.

24 Por. jednak Informacja o wynikach kontroli zbywania nieruchomości komunalnych przez gminy, NIK, Delegatura w Lublinie, Lublin, grudzień 2003, s. 46, gdzie, formułując wnioski de lege ferenda i nawiazując jednocześnie do zasad równości i jawności, terminu „jednolitość” używa się w kontekście jednolitości wykładni przepisów dotyczących tego trybu zawarcia umowy w celu wyeliminowania pojawiających się w praktyce rozbieżności interpretacyjnych. Taki sposób rozumienia jednolitości na gruncie reguł konstrukcyjnych przetargu wydaje się nieadekwatny.

Odrębnie jawność i jednolitość traktuje SN w wyroku z dnia 30 stycznia 2009, II CSK 437/08. Odmiennie R. Padrak, Sprzedaż nieruchomości..., s. 19. Stwierdza on, że przejawami zasady jawności i jednolitości postępowania są przepisy nakazujące publikowanie wykazów nieruchomości czy też ogłoszeń przetargów „[...] a ponadto przepisy normujące przebieg przetargów i rokowań, co w konsekwencji powoduje jednolite traktowanie wszystkich podmiotów ubiegających się o nabycie nieruchomości" (ibidem). Z wywodów autora trudno jednak wywnioskować, na czym polegają te konsekwencje. Ponadto autor w dalszych uwagach zdaje się również zacierać różnice między jednolitością postępowania a równością uczestników. 
Jednolitość postępowania wynika z istoty przetargu jako postępowania wielostronnego. Wielość uczestników postępowania ubiegających się w toku jednej procedury o zawarcie oznaczonej umowy wyklucza zasadniczo indywidualne uzgadnianie treści stosunku przetargowego zachodzącego na linii indywidualny uczestnik - organizator, z pominięciem pozostałych uczestników. Dopuszczenie takiej ewentualności nieuchronnie prowadziłoby do dezintegracji całego postępowania, niwecząc jego sens. Taki indywidualnie modyfikowany tok czynności można by postrzegać nie jako jedno postępowanie, ale jedynie jako sumę równolegle prowadzonych negocjacji z poszczególnymi uczestnikami. Stąd niedopuszczalne są odstępstwa od zaprogramowanego $\mathrm{w}$ ogłoszeniu (ewentualnie także w regulaminie) toku postępowania zmierzającego do zawarcia umowy. Podkreślić wyraźnie należy, że chodzi tu jedynie o takie modyfikacje, które są uzgadniane indywidualne, a nie (abstrahując od ich dopuszczalności przepisami prawa) zmian toku postępowania dotyczących wszystkich uczestników ${ }^{26}$.

Zasada równego dostępu do udziału w przetargu z pewnością akcentuje taką samą dla ogółu potencjalnie zainteresowanych nabyciem własności nieruchomości możliwość przystąpienia do procedury prowadzącej do zawarcia umowy sprzedaży. Jednak bardziej adekwatne dla wyczerpującego scharakteryzowania tego aspektu procedury przetargowej byłoby raczej mówienie o zasadzie równości jako takiej, bez użycia sformułowań mogących $\mathrm{w}$ jednym $\mathrm{z}$ dopuszczalnych sposobów rozumienia sugerować, że chodzi tylko o jeden z etapów przetargu (tu: początkowy, skoro mowa o dostępie do przetargu). W ten sposób usuwamy wywołany powyższym, „cząstkowym” sformułowaniem zasady równości dylemat, czy obejmuje ona inne przejawy równego statusu podmiotów ubiegających się o zawarcie umowy, w szczególności równe dla wszystkich kryteria oceny i wyboru oferty przetargowej.

Zasada równości powinna być rozpatrywana na trzech płaszczyznach: kryteriów uzyskania statusu uczestnika przetargu, pozycji osoby, która już nabyła status uczestnika postępowania (w zakresie pactum de procedendo) oraz kryteriów wyboru oferty przetargowej. Nie zawsze jednak, w ramach omawianej procedury, pozycja podmiotów prawa jest taka sama we wszystkich okolicznościach. Podstawowy przypadek, który można postrzegać jako swego rodzaju uprzywilejowanie oznaczonej kategorii osób już na etapie wyboru rodzaju przetargu, określa art. 29 ust. $3 b$ u.g.n.r. (przetarg ograniczony), ex definitione pociągający za sobą eliminację podmiotów potencjalnie zainteresowanych uczestnictwem, niespełniających jednak określonych kryteriów wymaganych od uczestników. Jako pewna idea jest on jak najbardziej godny aprobaty, skoro dysponowanie nieruchomościami przez ANR nie może ograniczać się do realizacji wyłącznie funkcji dochodowej (generowania 
zysków ze sprzedaży). Mając na uwadze precyzję wywodu, podkreślenia wymaga, że nie powinno się, rozważając ten przejaw zasady równości, mówić o równości uczestników przetargu, skoro chodzi o aspekt regulacji prawnej przetargu, w którym nikt jeszcze nie nabywa przymiotu uczestnika postępowania. W ramach procedury przetargowej, jako czyniący wyłom w regulacji takiej samej pozycji uczestników na drugiej z wyróżnionych wyżej płaszczyzn, należy zwrócić uwagę na przepisy zwalniające od wniesienia wadium osoby fizyczne posiadające prawo do rekompensaty za mienie pozostawione poza granicami Rzeczypospolitej Polskiej (art. 29 ust. 3f oraz $§ 10$ rozporządzenia z 17 lutego 2010 r.). Z kolei w materii regulującej wybór oferty, wyrazem preferencji dla pewnych kategorii nabywców jest art. 29 ust. 3, skoro w razie złożenia kilku (co najmniej dwóch) równorzędnych ofert dokonuje się wyboru spośród tych uczestników, którzy spełniają określone przesłanki. Zauważmy, że w pozostałych przypadkach, jeżeli ze względu na równorzędność ofert wybór jest utrudniony, komisja przetargowa przeprowadza dodatkowy przetarg ustny, który jest ograniczony do uczestników składających te oferty (§ 21 ust. 4).

Z pewnością jednak przywołane wyżej przypadki zróżnicowania pozycji niektórych uczestników przy gospodarowaniu gruntami ZWRSP nie sposób traktować jako arbitralne odstępstwa od zasady równości uczestników przetargu. Powszechnie przyjęta jest dopuszczalność odstępstw od jednakowego uregulowanie praw i obowiązków podmiotów prawa, o ile dostatecznie poważne racje stanowią uzasadnienie dla odmiennego potraktowania jakiejś klasy podmiotów wyróżniających się relewantną cechą 27 . Dla wskazanych wyżej odstępstw od takiego samego potraktowania uczestników postępowania (ewentualnie osób dopuszczanych do przetargu w procedurze ograniczonej) bez trudu można podać przesłanki je uzasadniające, mające zakorzenienie $w$ wartościach będących podstawą dla sformułowania zadań ANR, jak i wynikających z przepisów Konstytucji (art. 23), czy też - jak w przypadku zwolnienia od wniesienia wadium - w silnie uzasadnionych aksjologicznie tendencjach reprywatyzacyjnych.

Zasada najkorzystniejszego wyniku przetargu odzwierciedla fundamentalny gospodarczy sens procedury przetargowej - jest on wszak organizowany po to, aby zapewnić organizatorowi możliwie korzystne świadczenie ze strony osób zainteresowanych zawarciem umowy, dla której zorganizowano procedurę ${ }^{28}$. Należy wyraźnie podkreślić, że kryteria wyboru oferty zarówno przy przetargu (aukcji) „,kodeksowym," jak i na gruncie rozwiązań szczególnych takich jak u.g.n.r. powinny być z góry określone w warunkach postępowania według obiektywnie weryfikowalnych wskaźników. Niedopuszczalne jest ustanowienie jako kryterium wyboru subiektyw-

Por. w tej kwestii rozważania M. Safjana, Autonomia woli a zasada równego traktowania, (w:) Zaciaganie i wykonywanie zobowiązań. Materiały III Ogólnopolskiego Zjazdu Cywilistów (Wrocław, 25-27.09.2008 r.), pod red. E. Gniewka, K. Górskiej i P. Machnikowskiego, Warszawa 2010, s. 357 i nast. 
nej oceny organizatora ${ }^{29}$. W tym kontekście widać, że omawiana zasada refleksowo pełni swego rodzaju funkcję gwarancyjną dla uczestnika postępowania, który z góry wie, na co może liczyć, uczestnicząc w postępowaniu i zabezpiecza go przed arbitralnymi decyzjami organizatora.

O ile u.g.n. w art. 40 ust. 2 stanowi wprost, że przetarg ustny ma na celu uzyskanie najwyższej ceny, zaś przetarg pisemny - najkorzystniejszej oferty, to brak takiego postanowienia w u.g.n.r. Natomiast rozporządzenie z dnia 17 lutego 2010 r. w zd. $2 \S 15$ stanowi, że przetarg ustny wygrywa ten uczestnik, który zgłosił najwyższą cenę. Przy przetargu ofert w ogłoszeniu inicjującym postępowanie należy zawrzeć postanowienia wskazujące kryteria oceny ofert ( $\$ 7$ ust. 3 pkt 9, lit. b - jak stąd wynika, nie ograniczają się one do wysokości ceny. Komisja przetargowa wybiera, inaczej niż przy przetargu ustnym - ofertę najkorzystniejszą. Z kolei z treści $§$ 21 ust. 2 zd. 2 pośrednio wynika, jakie inne poza ceną kryteria oceny można wskazać w ogłoszeniu. Są to również warunki wykupu przynależności oraz deklarowany poziom zatrudnienia pracowników. Względy racjonalnego wykorzystania potencjału gruntów Zasobu uzasadniają także umieszczenie tu planu gospodarowania z wykorzystaniem nabywanego gruntu.

Wprawdzie w obrębie przetargowej regulacji u.g.n.r. i aktów wykonawczych wydanych na jej podstawie występuje - odrębnie dla procedury ustnej i pisemnej kategoria najwyższej ceny i najkorzystniejszej oferty, a Kodeks cywilny zawiera jedynie pojęcie oferty najkorzystniejszej (art. $70^{2} \S 1 \mathrm{kc}$.), to nie ma podstaw do mówienia tu o jakichś istotnych różnicach pomiędzy tymi aktami. Jest tak, ponieważ na gruncie u.g.n.r. powyższe pojęcia pojawiają się w przepisach dotyczących przetargu prowadzącego do zawarcia umowy sprzedaży nieruchomości ZWRSP - ten typ umowy determinuje nazewnictwo, którym posługuje się prawodawca. Ponieważ przetarg ustny służy jedynie określeniu ceny - stąd pojęcie najwyższej ceny (które to pojęcie na gruncie reguł znaczeniowych zarówno języka powszechnego, jak i prawnego jest węższe niż pojęcie „,najkorzystniejszej oferty”). Skoro oferta w przetargu pisemnym może zawierać również propozycje innych postanowień umownych, pojęcie „najwyższej ceny” byłoby za wąskie. Przetarg (aukcja) kodeksowy jest uniwersalnym trybem zawarcia różnych typów umów, stąd pojawia się tam jedynie określenie „,najkorzystniejsza oferta” jako odpowiednio szerokie dla różnych umów typowych, jak i nienazwanych.

Do innych, moim zdaniem nietrafnych wniosków dochodzi M. Boratyńska, zob. taż, Przetarg w prawie polskim..., s. 88. Stwierdza ona: „[...] niektóre kryteria podawane w ogłoszeniach nie poddają się kwantyfikacji”, w przypadku zaś kombinacji jako kryterium oceny korzystności oferty większej liczby różnych kryteriów (np. wysokość sumy pieniężnej i liczba zatrudnianych pracowników w przypadku zbycia przedsiębiorstwa) nie sposób, zdaniem autorki porównywać ich ze soba w sposób zobiektywizowany. Jedyna osoba miarodajna dla oceny ofert jest w takiej sytuacji sam ogłaszający i nie sposób zastępować jego ocen ocenami innego podmiotu, w szczególności sądu. Sąd mógłby dokonać rozstrzygnięcia jedynie wówczas, gdy w ogłoszeniu podane zostały jednoznaczne kryteria oceny, a ogłaszający zobowiązał się do wyboru którejś z ofert. 
Nadmiernym uproszczeniem byłoby jednak poprzestanie bez komentarza na stwierdzeniu, że należałoby postawić znak równości między pojęciami „najkorzystniejszej oferty" $i$,najkorzystniejszego świadczenia z umowy sprzedaży”. Zwłaszcza takie postanowienie oferty, jak liczba zatrudnianych pracowników, plan prowadzonej działalności, nie mogą być traktowane jako essentialia umowy sprzedaży. Pojęcie „najkorzystniejszej oferty” oznacza, że na zwycięskim uczestniku przetargu, obok świadczenia należącego do esencjaliów umowy sprzedaży (zapłaty ceny), spoczywały będą również inne obowiązki, które jednak zachowują odrębność w strukturze świadczenia z umowy zawieranej przez ANR z wyłonionym w przetargu kontrahentem ${ }^{30}$.

W kontekście rozważań nad zasadą najkorzystniejszej oferty wypada wspomnieć o rozwiązaniach przewidzianych w zdaniach drugim i trzecim art. 29 ust. 3, zgodnie z którymi $w$ razie złożenia kilku równorzędnych ofert pierwszeństwo ma osoba podlegająca przepisom o ubezpieczeniu społecznym rolników oraz pracownik i spółka pracowników zlikwidowanego ppgr. Jeśli więcej niż jednemu oferentowi przysługuje pierwszeństwo, wybiera się tego z nich, który daje najlepszą gwarancję prowadzenia gospodarstwa. Nie należy poczytywać tych postanowień za formułujące szczególny przypadek kryteriów oceny oferty jako najkorzystniejszej, ale należy je ujmować jako uprzywilejowanie wymienionych tam podmiotów. Przepis wyraźnie stanowi, że w razie złożenia równorzędnych ofert wybiera się tę złożoną przez wskazany tam podmiot. Skoro, verba legis, oferty są równorzędne, to oznacza, że prawodawca rozstrzygnął o zastosowaniu innego niż korzystność oferty kryterium wyboru. A jak już wcześniej wspomniałem, w pozostałych przypadkach złożenia ofert równorzędnych przeprowadza się dodatkową licytację.

Z przetargowym trybem zawierania umów immanentnie związany jest aspekt konkurencji uczestników postępowania. M. Boratyństa stwierdza, że „celem przetargu jest [...] wywołanie konkurencji i właśnie po to instytucja ta istnieje" ${ }^{31}$. R. Szostak w wielu swoich publikacjach, na kanwie rozważań poświęconych temu trybowi zawierania umów, wymienia zasadę uczciwej konkurencji, stwierdzając, że stanowi ona fundament przetargowego trybu zawarcia umowy. Pisze on, że zasady uczciwej konkurencji wynikają $\mathrm{z}$ adhezyjnego ustalenia między organizatorem a uczestnikami, a liczy się tu przede wszystkim zakaz wchodzenia w zmowę z innymi uczestnikami postępowania, niedozwolonego rozpowszechniania informacji mogących mieć wpływ na wynik przetargu, podawania nieprawdziwych danych, udzielania nierze-

$30 \quad$ Kwestia jest jednak sporna - w sumie uznanie, które wynikające z czynności prawnych obowiązki należą do treści jednego stosunku prawnego, a które tworzą odrębny stosunek funkcjonalnie powiazany z pierwszym, to w pewnym stopniu kwestia konwencji, jakkolwiek może to niekiedy powodować doniosłe konsekwencje; por. przykładowo kontrowersje w doktrynie co do samodzielnego charakteru zastrzeżenia zadatku: M. Tenenbaum, Instytucja zadatku..., s. 131 i nast. 
telnych wyjaśnień co do treści oferty ${ }^{32}$. Sama konkurencja, w języku ogólnym pojmowana jako rywalizacja, współzawodnictwo ${ }^{33}$ uczestników dążących do zawarcia umowy, jest rzeczywistym, realnym efektem faktu prowadzenia postępowania przetargowego zgodnie z pactum de procedendo. Jest bezpośrednią konsekwencją tego, że w tym trybie kontraktowania modelowo mamy do czynienia $\mathrm{z}$ wieloma uczestnikami postępowania dążącymi do zawarcia jednej umowy. Zachowaniu uczciwej konkurencji służą te rozwiązania, które mają zapewnić bezstronność komisji przetargowej (zob. § 11 ust. 2 rozporządzenia z dnia 17 lutego 2010 r.).

\subsection{Charakter i relacje między zasadami przetargu na sprzedaż nieruchomości publicznych, w tym ZWRSP}

Zaprezentowane powyżej zasady przetargu na sprzedaż nieruchomości ZWRSP mają różny charakter i zasięg oddziaływania. Ze względu na te kryteria należy dokonać ich kwalifikacji pod względem aktualności dla różnych form dysponowania gruntami ZWRSP, ustalić, jakie zachodzą pomiędzy nimi związki, jak i umiejscowić w obrębie podziału na zasady w sensie dyrektywalnym i opisowym.

Najbardziej ogólny charakter ma zasada prawidłowej gospodarki, aktualna dla wszystkich form dysponowania gruntami Zasobu, ,przenikająca” całość regulacji prawnych działalności ANR podejmowanej względem nieruchomości, którymi gospodaruje jako powiernik Skarbu Państwa. Może być ujmowana jako dyrektywa nakazująca dokonywanie czynności dotyczących mienia Zasobu w sposób maksymalnie korzystny z perspektywy realizacji zadań ANR. Z racji na jej szeroki zakres zastosowania trudno byłoby ją jednak ujmować jako zasadę specyficzną tylko dla przetargu na sprzedaż nieruchomości Zasobu.

Z pewnością dużo większe znaczenie dla praktycznego funkcjonowania instytucji przetargu ma zasada jawności. Poprzez obowiązek sporządzenia i upublicznienia wykazu nieruchomości przeznaczonych do zbycia jest aktualna, obok procedury przetargowej, również dla przypadków sprzedaży bezprzetargowej oraz innych form dysponowania gruntami Zasobu takich jak zamiana nieruchomości. Ma ona również, na co zwracałem uwagę, odbicie w szczegółowych uregulowaniach w ramach instytucji przetargu na sprzedaż. Jej sformułowanie jest zatem raczej wynikiem quasi-indukcyjnego wnioskowania, mającego za podstawę szereg wspomnianych szczególnych unormowań. Nie wynika z jednego tylko, szczególnie istotnego przepisu, który należałoby traktować dla niej jako fundamentalny ${ }^{34}$. Postrzegana jako zasada opiso-

R. Szostak, Zachowanie uczciwej konkurencji przy udzielaniu zamówień publicznych (cz. I), „Prawo Spółek” 2006, nr 10, s. 36.

34 Inaczej, nietrafnie SN w wyroku z dnia 11 maja 2005 r. III CK 562/04. SN uznaje, że zasada jawności sformułowana jest w przepisie art. 35 u.g.n., nie przywołując przy tym innych przepisów, z których można by ją wyprowadzić. Wniosek ten aprobowany jest przez część doktryny; tak przykładowo A. Tułodziecki, (w:) Ustawa o gospodarce nieruchomościami. Komentarz, pod red. M. Wolanina, Warszawa 2009, s. 192. 
wa, określa pewien model możliwego i aktualnie obowiązującego rozwiązania normatywnego. Jest zdaniem stwierdzającym, że de lege lata jawność jest wartością znajdującą odzwierciedlenie w obowiązujących rozwiązaniach normatywnych. Jako norma prawna, o czym była mowa, ustanawia nakaz dokonywania czynności publicznie oraz takiego też udostępniania wyników dokonanych czynności.

Również zasada ekwiwalentności nie jest specyficznym dla przetargu rozwiązaniem $^{35}$, aczkolwiek niezwykle istotnym dla jego uregulowania. Nie uważam, żeby można było tu mówić o normie nakazującej w określony sposób ustalać cenę nieruchomości (stąd nie należy tu mówić o zasadzie w sensie dyrektywalnym). Mówimy raczej o zespole przepisów dookreślających zakres zastosowania normy, której zrąb ustanawia art. $353^{1} \mathrm{kc}^{36}$ Zasada ekwiwalentności wyznacza granice swobody okreŚlenia treści stosunku prawnego sprzedaży nieruchomości ZWRSP. Jako o zasadzie należy o niej mówić wyłącznie w znaczeniu opisowym.

Równość i jednolitość postępowania to zasady, które należy widzieć w kontekście zasady uczciwej konkurencji. Ukształtowane według dwóch pierwszych zasad reguły postępowania $\mathrm{w}$ toku procedury przetargowej przy wielości uczestników wywołują efekt w postaci konkurencji między nimi. Do mechanizmu konkurencji, rozumianego jako realnie istniejące relacje między uczestnikami postępowania, w aspekcie normatywnym odnosi się właśnie zasada uczciwej konkurencji. Równość i jednolitość postępowania stymulują zaistnienie konkurencji, a w rezultacie osiąga się efekt wieńczący tok przeprowadzonych czynności w postaci przyjęcia najkorzystniejszej oferty. Jest to gospodarczym celem przetargu. Właśnie w tak przedstawionym uwikłaniu najlepiej zaprezentować oddziaływanie na siebie wymienionych zasad, aby w należyty sposób uwypuklić ich znaczenie dla tego trybu zawarcia umowy.

Zasada uczciwej konkurencji rozpatrywana w ujęciu dyrektywalnym w swojej strukturze przypomina zasadę prawidłowej gospodarki. Nie sposób jej sprowadzić tylko do ogólnie sformułowanej powinności przestrzegania reguł wynikających z pactum de procedendo. Byłoby to zabiegiem jałowym, a nawet błędnym metodologicznie, skoro i tak rozpatrując naruszenie reguł postępowania przetargowego w danych okolicznościach, zawsze orzekałoby się o naruszeniu konkretnej powinności (np. dopuszczenie do przetargu osoby, która nie wniosła wadium, dopuszczenie do przetargu ograniczonego osoby, która nie spełnia ustawowych kryteriów), a nie jakiejś zupełnie nieskonkretyzowanej zasady w podanym wyżej brzmieniu. Z przywoływanych wcześniej rozważań R. Szostaka wynika, że przy zasadzie uczciwej konkurencji chodzi raczej o segment zasad słuszności, a więc reguł pozaprawnych, które powinny być jednak przestrzegane w toku procedury przetargowej. 
Zakwalifikowanie konkretnego zachowania jako naruszającego uczciwą konkurencję ułatwia stwierdzenie, że narusza ono dobre obyczaje (które są kategorią szerszą). Jej podobieństwo do zasady prawidłowej gospodarki polega zaś na tym, że sama nie formułuje określonych reguł postępowania, ale nakazuje branie pod uwagę przy wykonywaniu powinności wynikających ze stosunku przetargowego reguł pozaprawnych $^{37}$. Jako sankcję naruszenia zasady uczciwej konkurencji należy brać pod uwagę w pierwszym rzędzie wzruszalność zawartej umowy na podstawie art. $70^{5} \mathrm{kc}$.

W przypadku zasady równości rozpatrywanej jako norma prawna proces jej pozyskania jest podobny do wyinterpretowania zasady jawności - mamy do czynienia z normą wyinferowaną poprzez wnioskowanie z szeregu rozwiązań szczegółowych. Jednolitość zaś nie jest znowu (podobnie jak ekwiwalentność) samodzielnym nakazem. Indywidualna modyfikacja porozumienia przetargowego między organizatorem a konkretnym uczestnikiem nie jest zachowaniem sprzecznym z jakimś zakazem, ale raczej działaniem poza obszarem kompetencji do kształtowania porozumienia przetargowego, obszaru zakreślonego przez prawodawcę w przepisach u.g.n.r. i wydanych na jego podstawie przepisów wykonawczych. Chodzi tu jednak nie o zakres kompetencji w kształtowaniu umowy, której zawarcie jest gospodarczym celem przetargu, ale o pactum de procedendo, będącego wszak źródłem swoistego stosunku zobowiązaniowego.

Trudno byłoby natomiast stwierdzić, że któraś z omówionych zasad samoistnie przesądza o specyfice instytucji przetargu na sprzedaż nieruchomości publicznej, w tym nieruchomości ZWRSP ${ }^{38}$. To właśnie odwołanie się do zestawu zasad daje pełen obraz omawianej instytucji.

W konsekwencji wszystkie przywołane wyżej zasady, gdy ujmuje się je w znaczeniu wyłącznie opisowym, dają razem sprawozdawczą charakterystykę węzłowych punktów ukształtowania instytucji przetargu na sprzedaż nieruchomości publicznych, w tym nieruchomości ZWRSP.

Należy zauważyć, że w rozważaniach doktrynalnych posługuje się tymi pojęciami raczej intuicyjnie, bez wyraźnego akcentowania teoretycznoprawnych aspektów koncepcji zasad prawa i w ten też sposób formułuje się zasady postępowania przetargowego. Ich praktyczna doniosłość najczęściej sprowadza się do uzasadnienia zastosowania sankcji nieważności czynności prawnej. Odwołanie się do jakiejś zasady czy też, inaczej rzecz ujmując, określenie, że dane zachowanie narusza zasadę, lepiej uzasadnia wniosek, że konsekwencją takiego postępowania jest zastosowanie sankcji nieważności czynności prawnej. Jeśli, przykładowo, wskazując kon-

37 W przypadku zasady uczciwej konkurencji - reguł słusznościowych, w przypadku zasady prawidłowej gospodarki - reguł mających przede wszystkim (choć nie jedynie) charakter ekonomiczny.

38 Należy jednak podkreślić, że w piśmiennictwie zwłaszcza R. Szostak zdaje się wyróżniać szczególnie zasady równości oraz uczciwej konkurencji charakteryzując instytucję przetargu w ogólności. Nawet jeśli by przyjać, że powyższe zasady wysuwają się na czoło w toku charakterystyki instytucji przetargu, to nie sposób nie dostrzec że są daleko niewystarczające dla jej pełnej charakterystyki. 
sekwencje naruszenia przepisów mających urzeczywistniać jawność postępowania, powiemy o naruszeniu nie jawności jako takiej, ale zasady jawności, w praktyce uzyskujemy silniejszy efekt perswazyjny, nawet jeśli nie towarzyszy temu stwierdzeniu żadna precyzyjnie zarysowana koncepcja zasad prawa. Warto jednak uświadamiać sobie, czym pod względem teoretycznym jest zasada prawa dla lepszego zrozumienia mechanizmu ustalania konsekwencji dokonywanych czynności. Gdyby, przykładowo, doszło do określenia ceny wywoławczej na poziomie niższym niż wynikający z wyceny rzeczoznawcy, dla ustalenia konsekwencji takiego zdarzenia można posłużyć się prostym określeniem, że naruszono zasadę ekwiwalentności. Bardziej precyzyjnie, jednak bez uzyskania efektu wzmocnienia przez użycie terminu ,zasada” (a więc ustalenia odpowiednio wysokiej rangi danego przepisu), można by powiedzieć po prostu, że naruszono art. 30 u.g.n.r. Używając siatki pojęciowej z zakresu teorii prawa, można natomiast stwierdzić, że działanie to zostało dokonane poza granicami kompetencji wyznaczonej przez art. $353^{1} \mathrm{kc}$. dookreślanej $\mathrm{m}$. innymi przez przepis art. 30 u.g.n.r. To ostatnie stwierdzenie, najbardziej precyzyjnie pod względem dyscypliny metodologicznej określające konsekwencje takiego zdarzenia, jest jednak mało czytelne dla praktyków, jak i nieakceptowane przez niektórych przedstawicieli doktryny (nie wszyscy wszak akceptują ustalenia poznańskiej szkoły teorii prawa). Jest to konsekwencją naturalnego zróżnicowania poglądów, jak i przyjmowanych na wstępie prowadzonych rozważań założeń teoretycznoprawnych. Zaproponowane przeze mnie określenie nie może zostać uznane za niekontrowersyjne. Dlatego też faktycznie formułowane w doktrynie i orzecznictwie zasady przetargu, czy też gospodarowania nieruchomościami publicznymi mogą również być postrzegane jako swojego rodzaju platforma, gdzie ustala się to, co najważniejsze w konstrukcji danej instytucji prawnej poprzez wskazanie zwłaszcza podstawowych wartości, na bazie których funkcjonuje instytucja przetargu na sprzedaż nieruchomości publicznych.

Nie oznacza to jednak, że każdorazowe stwierdzenie naruszenia jakiejś zasady musi prowadzić do uznania zawartej umowy za nieważną - a więc, że nieważność umowy jest tego konieczną konsekwencją. W istocie chodzi przede wszystkim o takie naruszenie przepisów dotyczących procedury na sprzedaż nieruchomości publicznych, w tym gruntów Zasobu, które wpływa na jego wynik ${ }^{39}$. Nie sposób przeoczyć roli zasad postępowania przetargowego przy budowaniu dyrektyw interpretacyjnych w toku wykładni odnośnych przepisów regulujących ten tryb zawarcia umowy. $\mathrm{Z}$ pewnością $\mathrm{w}$ razie wątpliwości należy przyjmować takie ich znaczenie, które najlepiej służy realizacji wartości, leżących podstaw sformułowania poszczególnych zasad. 


\title{
Legal principles of a tender procedure for the sale of the properties belonging to the Agricultural Property Resources of the State Treasury
}

\begin{abstract}
Key words: tender, legal principle, proper management, Agricultural Property Agency

Tender is fundamental procedure leading to conclusion of the sale agreement of the properties belonging to the Agricultural Property Resources of the State Treasury in accordance with the Act on the Management of Agricultural Properties owned by the State Treasury. The author distinguishes several principles, which shall be applied to the above way of conclusion of the sale agreement. The general principle of the proper management reflects in all legal forms of disposition of agricultural properties owned by the State Treasury. Its violation doesn't cause an invalidity of the sale contract. Appropriate principles, which shall be applied to the tender are as follows: principle of openess, principle of equal treatment and equal access to the tender, principle of fair competition, principle of uniformity and principle of equivalency. Unlike opinions in legal doctrine, the author states that the openess and uniformity are the separate principles. All principles indicate values on which the legal institution of the tender is founded. These principles are also the grounds to formulate the rules of interpretation, which are useful during the operation of decoding of the legal norms.
\end{abstract}

